\title{
COSTA RICA: \\ UN RETO SOCIAL PARA LOS MIGRANTES COLOMBIANOS
}

Sebastian Polo Alvis

Enrique Serrano López

Laura Alejandra Granados Vela

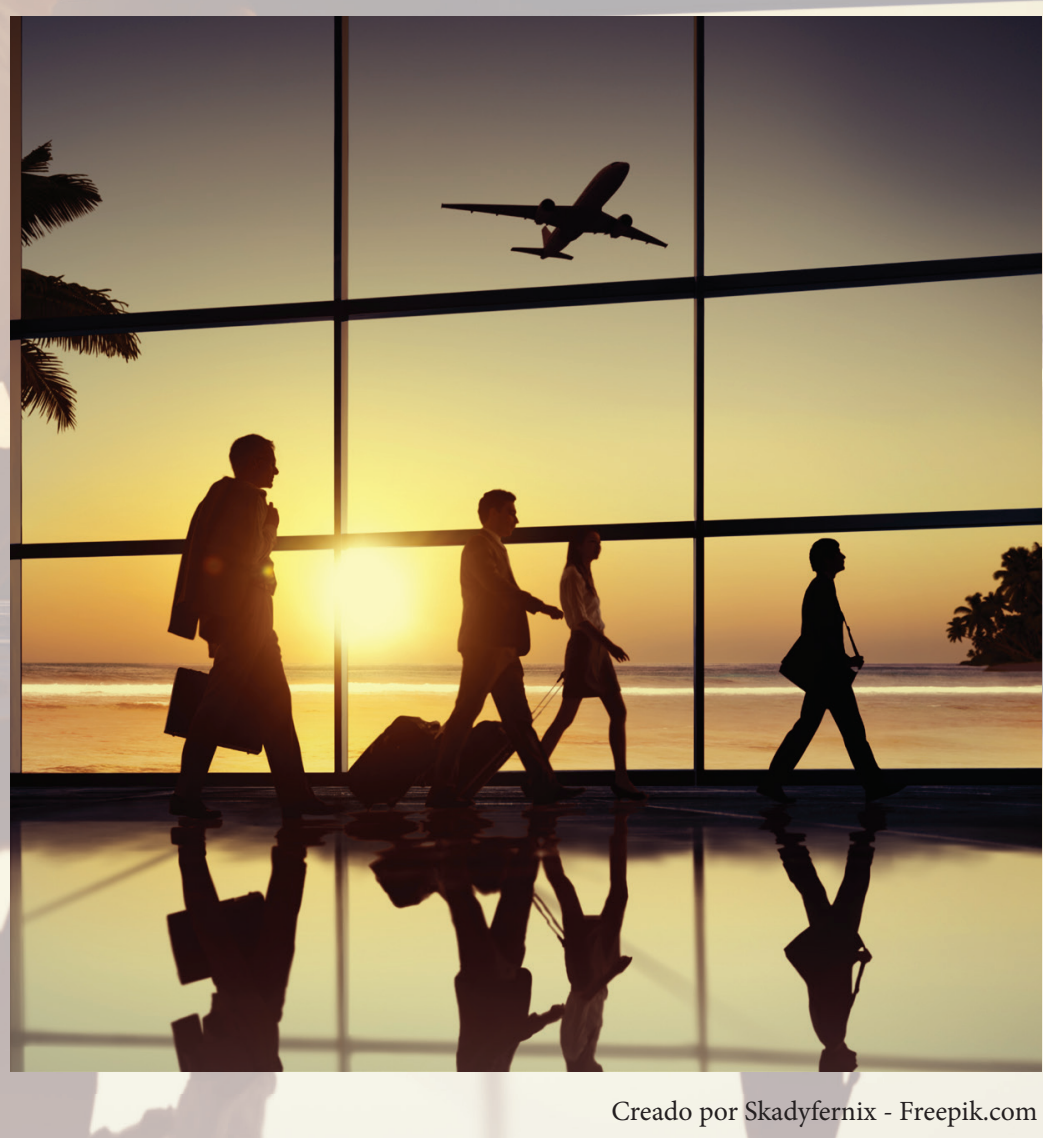





\title{
COSTA RICA: UN RETO SOCIAL PARA LOS MIGRANTES COLOMBIANOS*
}

\author{
Sebastian Polo Alvis \\ ENRIQUe SERRano LÓPEZ \\ Laura Alejandra Granados Vela \\ UNIVERSIDAD DEL ROSARIO
}

\section{Resumen}

El presente trabajo pretende comprender cuáles son las condiciones actuales de los colombianos en la sociedad costarricense y cuáles han sido los procesos de vinculación en dicho país. Entender estas circunstancias permite tener una perspectiva más completa de los migrantes colombianos en Costa Rica, que incluyan las condiciones sociopolíticas existentes en la sociedad del país receptor y faciliten un mayor seguimiento de los colombianos desde el país emisor. Mediante la comprensión estadística y demográfica de las condiciones socioeconómicas de la población colombiana en Costa Rica y de un estudio etnográfico sobre las perspectivas y experiencias personales de migrantes colombianos, se busca que el lector tenga una visión fidedigna de la migración colombiana a ese país, enmarcada en un análisis histórico social de esta tendencia migratoria.

Palabras clave: migración, Colombia, Costa Rica, adaptación social, América Latina.

Los autores: Sebastian Polo Alvis, joven investigador del grupo de Estudios políticos e internacionales de la Universidad del Rosario. Correo electrónico: spoloa92@gmail.com

Enrique Serrano López, profesor de planta e investigador de la Universidad del Rosario. Correo electrónico: enriqueserrano3@gmail.com

Laura Alejandra Granados Vela, asistente voluntaria de investigación en el grupo de estudio Conflicto y sociabilidades y del semillero Migraciones colombianas hacia el exterior de la Universidad del Rosario. Correo electrónico: laura.granados@urosario.edu.co

Recibido: 18 de septiembre de 2017; evaluado: 4 de octubre de 2017; aceptado: 18 de octubre de 2017.

La presente investigación se realizó en el marco del Semillero de Migraciones Colombianas al Exterior de la Universidad del Rosario. Los autores agradecen a Ángela Mora por su colaboración para la realización de este artículo. 


\title{
COSTA RICA: A SOCIAL CHALLENGE FOR COLOMBIAN MIGRANTS
}

\author{
Sebastian Polo Alvis \\ ENRiQue Serrano López \\ Laura Alejandra Granados Vela \\ UNIVERSIDAD DEL ROSARIO
}

\begin{abstract}
This paper aims to understand the current conditions of the Colombian people in Costa Rican society, as well as the social integration processes in the country. By understanding these circumstances, it is possible to have a broader perspective of Colombian migrants in Costa Rica that includes the sociopolitical conditions of the host country's society and that facilitates a greater follow-up of Colombians. By understanding the statistics and demographics of the socioeconomic conditions of the Colombian population in Costa Rica and conducting an ethnographic study on the perspectives and personal experiences of Colombian migrants, we aim to provide the readers with a reliable vision of Colombian migration to that country, framed in a socio-historical analysis of this migration tendency.
\end{abstract}

Key words: Migration, Colombia, Costa Rica, Social integration, Latin America.

About the authors: Sebastián Polo Alvis, researcher for the Group of Political and International Studies from Universidad del Rosario. E-mail: spoloa92@gmail.com

Enrique Serrano López, associate professor and researcher at Universidad del Rosario. E-mail: enriqueserrano3@gmail.com

Laura Alejandra Granados Vela, volunteer research assistant for the study group "Conflicto y sociabilidades" and of the research incubator "Migraciones colombianas hacia el exterior" at Universidad del Rosario. E-mail: laura.granados@urosario.edu.co

Received: September 18, 2017; evaluated: October 4, 2017; accepted: October 18, 2017. 


\section{Introducción}

A lo largo de su historia, Costa Rica se ha caracterizado por ser un país reticente a la inmigración. Durante el siglo XIX, se implementaron leyes migratorias limitantes de cierre de frontera a ciertos grupos étnicos. Sin embargo, desde finales del siglo XX la migración aumentó significativamente gracias a las condiciones económicas y políticas llamativas del país, a pesar de que prevalecieron restricciones a la entrada de personas de determinados sectores socioeconómicos.

Entre los países de origen de los migrantes se destaca Colombia. Además de la relación económica que desarrollan con el país receptor, los retos a los que se enfrentan los colombianos están ligados a su integración a la sociedad costarricense, que ha tenido una percepción negativa de los migrantes porque observa al extranjero como un elemento negativo de otredad.

La estigmatización que hacen los costarricenses de los migrantes colombianos resulta un factor importante para ver la relación entre estas dos poblaciones en el plano migratorio. Por ello, el presente trabajo pretende exponer cuáles son las condiciones actuales de los colombianos en la sociedad costarricense y cuáles han sido sus procesos de adaptación social. Entender estas circunstancias permite una perspectiva más completa, que incluye las condiciones sociopolíticas existentes en la sociedad del país receptor y facilita un mayor seguimiento de los colombianos desde el país emisor.

El artículo se divide en dos partes: la primera tratará la migración histórica hacia Costa Rica, enfocada en la integración de esta en la sociedad receptora. La segunda analizará sus condiciones económicas y demográficas actuales y su proceso de inserción en Costa Rica mediante un compendio de entrevistas semiestructuradas de colombianos que han llegado a este país. Por último, se ofrecerán conclusiones y reflexiones sobre los hallazgos.

\section{Historia de la inmigración en Costa Rica}

Durante el dominio español, Costa Rica no fue un territorio colonizado ni poblado a gran escala por los conquistadores. Por ello, en 1821, después de la Independencia, los habitantes eran pocos y se concentraban en la costa pacífica, en ciudades pequeñas como Cartago y Ciudad del Espíritu Santo, al igual que en las inmediaciones de las ciudades de San José, Alajuela y Heredia. La población estaba compuesta en 
su mayoría por criollos (blancos y mestizos) y una buena parte del territorio aún no había sido explorada, por lo que no había un contacto directo con las pocas comunidades indígenas existentes.

Gracias a su aislamiento, Costa Rica nacía como Nación diferenciada de sus vecinos centroamericanos, que debían enfrentar problemas que este país no poseía, como la discusión sobre la anexión directa al Primer Imperio Mexicano o a las Provincias Unidas del Centro de América, la cual conllevó a una disputa ideológica en la que proliferaron guerras en la región. Así, tras su secesión de la República Federal de Centro América, en 1838, se distanció de las luchas internas entre liberales y conservadores y empezó a desarrollar su agricultura y comercio e impulsar la economía basada en las exportaciones de café. ${ }^{1}$

Uno de los objetivos de los primeros dirigentes costarricenses, como Francisco Morazán (1830-1834), José María Castro (1847-1849), Juan Rafael Mora (1849-1859) y Jesús Jiménez (1863-1866), fue atraer la migración para incentivar el crecimiento de la población y la colonización del territorio. Dado que los escasos pobladores costarricenses eran "predominantemente blancos", ${ }^{2}$ buscaban que la migración tuviera esa característica. De esta forma, se impulsó la migración de europeos, en especial provenientes de España, Inglaterra y Alemania. Desde 1826 hasta mediados de ese siglo, empezaron a buscarse incentivos que la promovieran.

En un inicio se decretó la libertad de culto en 1848 y luego se creó la Junta Protectora de Colonias, en 1850, que ofrecía a los europeos buenos contratos, servicio médico, registro de inmigración y la evaluación de algún problema con el inmigrante; sin embargo, no fue eficaz. En 1862 se promulgó la Ley de bases y colonización, que apuntaba a que se dispusieran los terrenos baldíos para los inmigrantes europeos y también prohibía el arribo de negros y chinos. ${ }^{3}$

1 Iván Molina, "Los pequeños y medianos caficultores, la historia y la nación. Costa Rica (1890-1950)", Caravelle 61, núm. 1 (1993): 62.

2 Raymond L. Woodward, "Las repúblicas centroamericanas" en Historia de América Latina: América Latina Independiente, 1820-1870, ed. Leslie Bethell (Barcelona: Crítica, 1992), 150.

3 Quendy Bermúdez, "Las leyes anti-inmigratorias y la inmigración china a Costa Rica", Acta Académica, núm. 50 (2012, mayo): 73; Zaida Fonseca, "Las migraciones chinas a Costa Rica en el siglo XIX" en Historia comparada de las migraciones en América Latina, coord. Patricia Galeana (Ciudad de México: Universidad Nacional Autónoma de México, Instituto de Investigaciones Jurídicas, 2016), 161-180; Guiselle Marín, "Españoles en la ciudad de San josé a finales del siglo XIX y principios XX", Anuario de Estudios Centroamericanos 2, núm. 25 (1999): 7-31; Marlene Loría y Alonso Rodríguez, "La inmigración china a Costa Rica. Entre la exportación y la exclusión 1870-1910", Revista de historia 2, núm. 44 (2001): 159-192. 
Empero, no se atrajo la población deseada, debido a que los incentivos no fueron efectivos, en particular por las condiciones con las que era recibida, caracterizadas por regiones de difícil acceso en Guanacaste, Turrialba y San Carlos, con clima complicado y bajos salarios. Por lo anterior, el país tuvo que aceptar migrantes "no deseados"4 para completar la mano de obra faltante. Así, empezaron a llegar chinos entre 1870 y 1890, que fueron concentrados en la construcción del ferrocarril del Atlántico y en grandes haciendas cafeteras. Las malas condiciones con las que fueron traídos y los malos tratos que recibían provocaron huelgas en las que exigían mejores condiciones laborales. ${ }^{5}$ Desde ese momento se observó que los costarricenses tenían recelo por cierta clase de migración. El trato indigno no era solo por razones de mano de obra barata, sino que tenía intrínseco un desprecio por esta población, lo cual repercutió de la siguiente manera:

[... todo evidencia que la vida para estos inmigrantes, a su llegada al país, fue difícil, no solo por desarraigo de su lugar de origen, sino porque se les sometía a un arduo sistema de trabajo, eran víctimas de violencia y engaño, y de la curiosidad y el desprecio por parte de algunos comerciantes locales y sectores allegados al gobierno. También fueron afectados por una serie de leyes de alto contenido discriminatorio y racista, que limitaron y prohibieron su ingreso, por considerarlos agentes "nocivos" contra la forma de vida de los costarricenses. ${ }^{6}$

A finales de ese siglo y a inicios del XX, basados en su percepción de los migrantes ideales para la colonización en Costa Rica, la población y los dirigentes costarricenses decidieron volver a impulsar la migración europea aun cuando la china y la japonesa eran más baratas y fáciles de atraer. ${ }^{7}$ Esto iba de la mano con la idea de modernización del país, que buscaba una europeización de las élites cafeteras y proponía que el desarrollo económico era acorde con el fortalecimiento de una raza blanca.

De esta manera, la migración de asiáticos y negros se prohibió de nuevo, mediante normas como el Decreto Ejecutivo No. 59 de 1896, el Decreto Ejecutivo No. 6 de 1897 y el Decreto Ejecutivo No. 1 de 1902. En ellos se enfatizaba en los controles para impedir el ingreso de "migrantes perjudiciales y nocivos para la forma de

\footnotetext{
Bermúdez, "Las leyes anti-inmigratorias", 74.

Fonseca, "Las migraciones chinas a Costa Rica en el siglo XIX", 170-171.

Loría y Rodríguez, "La inmigración china a Costa Rica", 177.

Bermúdez, "Las leyes anti-inmigratorias", 73-74.
} 
ser del costarricense", 8 en especial de los chinos. Aunque se aceptaron los que ya estaban establecidos en el país, se comenzó a exigírseles registros y documentos como una cédula de inmigración o, en 1924, si deseaban salir del país y volver, el pasaporte debía estar "firmado y sellado por el Gobernador, Capitán del Puerto y el Administrador de la Aduana, del punto de salida que no fueran otros que los Puertos de Limón y Puntarenas", 9 lo cual hacía su estadía más complicada. Tales condiciones fueron aumentando con los años, a raíz de la entrada ilegal de estos.

Para esa época también llegó migración proveniente de Medio Oriente hacia América Latina, por lo que Costa Rica se preparó para evitar su entrada al país. Así, el presidente Ascensión Esquivel Ibarra (1902-1906) emitió el Decreto Ejecutivo del 10 de junio de 1904, en el que también se prohibía el ingreso de población árabe, siria, libanesa y turca, entre otras. Un año después se impusieron condiciones de acceso a los migrantes sin distinción del lugar de origen; por ejemplo, se impidió el arribo de personas con trastornos mentales, discapacitadas, con ciertas enfermedades, criminales, etc. ${ }^{10}$

En la década de 1930, durante la presidencia del Ricardo Jiménez Oreamuno (1932-1936), se hizo aún más evidente que Costa Rica no solo restringía la llegada de migrantes de ciertas razas, sino que controlaba las condiciones socioeconómicas de la población que ingresaba, puesto que "la forma de ser del costarricense" abogaba tanto por una raza blanca como por una población modernizada. Por ello, se exigió que todo migrante debía demostrar que poseía una suma de dinero mayor a los mil colones, como garantía de su capacidad monetaria. ${ }^{11}$

Este tipo de leyes y decretos restrictivos a ciertas nacionalidades y razas llegó a su fin en 1943, cuando se celebró el Congreso demográfico interamericano en Ciudad de México, el cual buscaba que todos los países de la región eliminaran de sus jurisdicciones la prohibición de entrada y de interdicción a determinadas poblaciones o nacionalidades. ${ }^{12}$ Se emitió la Ley 51 de 1943, que derogó y suprimió todas las leyes y los decretos que impedían o restringían la entrada de migrantes chinos. ${ }^{13}$ Como esto sucedió bajo el discurso de la Segunda Guerra Mundial, estuvo

\footnotetext{
Bermúdez, "Las leyes anti-inmigratorias", 77.

Bermúdez, "Las leyes anti-inmigratorias", 72.

Bermúdez, "Las leyes anti-inmigratorias", 78.

Bermúdez, "Las leyes anti-inmigratorias", 78.

Bermúdez, "Las leyes anti-inmigratorias", 84.

Bermúdez, "Las leyes anti-inmigratorias", 83.
} 
relacionado con la apertura de las relaciones diplomáticas con la República de China y el reconocimiento de un apoyo diplomático a este país por su lucha contra el Eje.

Sin embargo, esta ley no se cumplió a cabalidad, debido a que en el Reglamento de Migración aún se mantenían las disposiciones discriminatorias a ciertas razas, que se hacían cumplir a la entrada al país. No fue sino hasta 1973 que la Asamblea Legislativa eliminó estas disposiciones del Reglamento. ${ }^{14}$

Como es notorio, el rechazo a varias nacionalidades y poblaciones fue evidente dentro de la política y la legislación migratoria costarricense hasta mediados del siglo XX. Ese hecho también se reflejó en la sociedad del país, que se oponían a la entrada y estadía de estas personas por múltiples motivos como su aspecto físico, sus costumbres, su comida y prejuicios infundados sobre su "inferioridad". ${ }^{15}$

A finales del siglo XIX, un grupo de nacionales le pidió al presidente Bernardo Soto (1885-1889) que eliminara la "epidemia" de los chinos, ya que estaba infectando con enfermedades incurables. Esto demuestra la percepción de la población frente a estos extranjeros, que además sufría malos tratos y era víctima de agresiones y ataques. A pesar de toda esa situación precaria, los inmigrantes lograron establecerse, formar sus propios negocios de comercio y continuar su vida en este territorio, aun cuando no estaban completamente inmersos en la población costarricense. ${ }^{16}$

Después de 1960, el éxodo hacia Costa Rica aumentó en relación directa con la migración transfronteriza proveniente de los países vecinos —ocasionada por sus crisis políticas internas - como Nicaragua, en donde se encontraba la dictadura de los Somoza (16.467 para 1963), el progresivo deterioro económico y el golpe de Estado liderado por la Guardia Nacional en 1968 en Panamá (2.755 para 1963), además de la presencia de poblaciones migrantes de Estados Unidos (2.051 para 1963). ${ }^{17}$

En las décadas del ochenta y del noventa, la mayoría de migrantes era refugiada de varias partes de la región como El Salvador, Cuba, Nicaragua, Guatemala y Colombia. Estos países atravesaban por dinámicas de conflictos internos enmarcados en el

\footnotetext{
Bermúdez, "Las leyes anti-inmigratorias", 86-88.

Fonseca, "Las migraciones chinas a Costa Rica en el siglo XIX", 171.

Fonseca, "Las migraciones chinas a Costa Rica en el siglo XIX", 171.

Instituto Nacional de Estadística y Censos de Costa Rica, VI censo nacional de población (San José: Dirección General de Estadistíca y Censos, 1963).
} 
discurso de la Guerra Fría. El Salvador, Guatemala y Colombia combatían contra guerrillas comunistas dentro de su territorio, mientras Cuba y Nicaragua tenían líderes socialistas en el poder y luchaban contra la injerencia estadounidense en sus procesos internos, lo que derivó en confrontaciones internas como con los contras en Nicaragua.

Muchos de los inmigrantes que llegaron entre esos años se asentaron en suburbios de las ciudades principales o intermedias, donde no tenían las mejores condiciones económicas y sociales. ${ }^{18}$ Esta situación continuó propiciando la percepción negativa de los costarricenses acerca de los inmigrantes, debido a que los últimos llegaban a los barrios pobres y los primeros sentían la amenaza de que los servicios públicos y los trabajos fueran acaparados por los inmigrantes.

Dentro de esa estigmatización se encuentran sobre todo los nicaragüenses, quienes conforman la población migrante más grande (Anexo 1). Estos se dedican al sector agropecuario y manufacturero y cuentan con grados de educación bajos, pues muy pocos tienen títulos técnicos o profesionales. ${ }^{19}$ Las razones por las que estas personas llegan a Costa Rica obedecen a la situación precaria de su país, que les impide acceder a salarios estables, servicios públicos y una calidad de vida estable. Por ello, al llegar a Costa Rica buscan ejercer cualquier actividad que les permita vivir mejor y enviar algo a su país de procedencia.

Para inicios del siglo XXI, se percibió dentro de la población y la política costarricense que la gran cantidad de inmigrantes constituía un tema de seguridad nacional, ya que el país estaba siendo "invadido" por estas personas; ${ }^{20}$ a ello se sumaba la preocupación de los nacionales de que los migrantes acapararían las oportunidades laborales y perjudicarían la calidad de la salud y la educación. ${ }^{21}$ Además, aumentó la pobreza, el desempleo, la inseguridad ciudadana y el deterioro de los sistemas de salud y educación, lo cual fue atribuido a la presencia de los extranjeros en Costa Rica, en particular a los nicaragüenses. ${ }^{22}$

18 Guillermo Acuña González y Edith Olivares Ferreto, La población migrante nicaragüense en Costa Rica: realidades y respuestas (San José: Fundación Arias para la paz y el progreso humano, 2000), 10.

19 Gabriela Segura, "Acceso a la regularización migratoria e integración social de las personas migrantes en Costa Rica”. https://estadonacion.or.cr/files/biblioteca_virtual/022/Equidad/Segura_2016.pdf (acceso octubre 8, 2017).

20 Luis Ernesto Aguilar, "Percepciones y actitudes de la población costarricense hacia la inmigración nicaragüense y la emigración de costarricenses al exterior", Pulso nacional, núm. 57 (2008, octubre): 5-9.

21 David Delgado, "Percepciones de la inmigración e integración en Costa Rica", Papeles de población 14, núm. 57 ( 2008, julio-septiembre), 86-87.

22 Delgado, "Percepciones de la inmigración e integración en Costa Rica", 85. 
Esta situación interna difícil con los migrantes también propició problemas diplomáticos con Nicaragua, que denunció xenofobia y malos tratos a sus nacionales en suelo costarricense y llevó la situación ante la Comisión Interamericana de Derechos Humanos; esta declaró inadmisibles las peticiones de Nicaragua bajo la Convención americana sobre derechos humanos, pero resalta que rechaza "todo acto de discriminación o xenofobia hacia la población migrante cualquiera que sea su origen, recordando que el régimen internacional de derechos humanos ha sido creado y funciona sobre la premisa básica de la igualdad entre todos los seres humanos". 23

A raíz de todo esto, en 2006 surgió una nueva Ley de migración y extranjería, la cual, entre otras cosas, fomenta la integración de los migrantes a la sociedad costarricense en busca de su desarrollo integral en conjunto con el desarrollo nacional. Esa Ley fue criticada internacionalmente porque tenía un enfoque de seguridad y control frente a los migrantes, pues se veía en ella una propensión a vulnerar sus derechos humanos. El Gobierno tuvo que ceder ante esta presión y reformarla en 2010; hizo énfasis en la integración de los migrantes y derogó algunas de las disposiciones más reprochadas. Esta Ley apunta a regular la situación de los migrantes ilegales en el país, pero fija cobros y multas para los que quieran acceder a estos beneficios, lo que dificulta el proceso. ${ }^{24}$

Si bien las leyes restrictivas frente a la inmigración se acabaron en 1973, en la población continúa el imaginario de Costa Rica como país blanco y por eso discrimina a las nacionalidades que no cumplan con ello dentro de su propio territorio. A los nicaragüenses se les percibe como amenazantes e inferiores, por lo que son excluidos del proyecto nacional y así se les impide que se integren a la sociedad de manera efectiva.

\section{Inmigrantes colombianos en Costa Rica desde los años 2000: Regularidad y refugio}

El incremento se presentó a partir de la década del noventa: de 5.898 en el censo nacional del año 2000 se pasó a 16.514 personas, según registros del censo nacional de 2011 y fue la segunda nacionalidad de migrantes más numerosa después de

23 Comisión Interamericana de Derechos Humanos, "Informe n 11/07 Caso interestatal 01/06 Nicaragua c. Costa rica 8 de marzo de 2007" http://www.cidh.org/annualrep/2007sp/casointerestatalsp.html (acceso octubre 8, 2017).

24 Segura, "Acceso a la regularización migratoria e integración social de las personas migrantes en Costa Rica". 
Nicaragua (Tablas 1 y 2). Esta tendencia migratoria es reciente, puesto que entre 1950 y 1984 la proporción de la población colombiana en el país centroamericano no era significativa e iba aumentando lentamente (Tabla 2).

Estos colombianos han salido del país en búsqueda de mayores oportunidades en el exterior. Si bien se ha relacionado parte de esta migración con el conflicto armado interno, algunas cifras demuestran lo contrario, ya que la mayoría corresponde a empresarios, comerciantes y profesionales que ven una oportunidad para expandir sus negocios u obtener estabilidad económica (Tabla 5). Por ello, es necesario examinar estos dos tipos de inmigrantes colombianos en Costa Rica. Se analizará primero a los refugiados colombianos de inicios de siglo (cuando aumentaron considerablemente) y luego a la inmigración colombiana regular.

Aunque las razones de los colombianos para migrar no están relacionadas en su mayor parte con el conflicto armado, sí es necesario mencionar a los refugiados colombianos en Costa Rica. En 2006, estos llegaron a 9.699 y en 2014, a 16.623. ${ }^{25}$ El incremento obedece a la situación interna, ${ }^{26}$ en especial a la insurgencia de grupos armados compuestos por desmovilizados paramilitares y a las guerrillas de las FARC y del ELN. Además de ello, Costa Rica resultó ser un destino deseado, debido a las oportunidades económicas que representaba.

Los refugiados que llegaron antes de 2006 eran, en su mayoría, hombres provenientes de Antioquia, Valle del Cauca y Cundinamarca, ${ }^{27}$ contaban con baja escolaridad y formaban familias monoparentales. Buena parte de ellos se asentó en San José, Heredia y Alajuela. Por su condición de refugiados, tienen seguimiento de entidades estatales y organizaciones internacionales como Acnur, las cuales brindan capacitación, asesoría, protección legal y beneficios sociales de salud, empleo y educación para ayudar a su inserción social y su condición económica. ${ }^{28}$

A pesar de dichos beneficios, algunos refugiados presentaron problemas para tener oportunidades de empleo y estabilidad económica. Para 2004, según una

25 Alto Comisionado de las Naciones Unidas para los Refugiados, "Population Statistics", http://popstats.unhcr. org/en/persons_of_concern (acceso octubre 8, 2017).

26 Mauricio Palma, "¿País de emigración, inmigración, tránsito y retorno? La formación de un sistema de migración colombiano", Oasis, núm. 21, (2015): 11.

27 Marjorie Chaves, "Refugiados colombianos en Costa Rica atendidos por la Asociación de consultores y asesores internacionales (ACAI)" (Tesis de pregrado, para optar por el grado de licenciatura en trabajo social, Cuidad universitaria Rodrigo Facio, 2006), 125.

28 Chaves, "Refugiados colombianos en Costa Rica", 60-64. 
encuesta realizada, solo $41 \%$ de los refugiados trabajaba. ${ }^{29}$ Las razones principales de esta dificultad fueron varias: en primer lugar, en muchos lugares no aceptan la documentación que les dan como refugiados y tampoco cuentan con los papeles que demuestren su experiencia laboral en Colombia; en segundo lugar, la percepción de los costarricenses sobre los colombianos y los refugiados, a los que relacionan con temas delictivos y poca confiabilidad. ${ }^{30}$ Esto provoca que se queden en viviendas humildes y arrendadas con sus familias, quienes resaltan que el trato con los vecinos y propietarios es adecuado. Aquellos que no están en Costa Rica con sus familias se ven obligados a convivir con otras personas, ya sean costarricenses, colombianos o nicaragüenses, con los que establecen lazos de apoyo que facilitan la inmersión en el país. ${ }^{31}$

La población de refugiados que encuentra trabajo también cuenta con dificultades, sobre todo por su poco conocimiento sobre la legislación interna y por la necesidad de cubrir sus necesidades básicas. Muchos deben laborar horas extras, no tienen vacaciones anuales ni día de descanso semanal. Además, algunos trabajos no incluyen seguridad social o seguro de riesgo laboral y tampoco tienen las condiciones económicas para acceder a ello, lo cual supone un problema para su condición de vida. Aunado a esto, varios consideran que el salario que les pagan no es el que corresponde a sus labores (50 \%), no reciben aguinaldo — primas- $(51,6 \%)$ y aquellos que fueron despedidos no tuvieron cesantías ni beneficios que debe obtener todo trabajador $(54,8 \%) .32$

Buena parte de los colombianos refugiados señalan que han recibido buenos tratos, en especial de los usuarios del lugar donde laboran, quienes no hacen distinción por su nacionalidad (Gráfico 2). Los pocos refugiados que estudian apuntan a mejorar sus condiciones laborales al adquirir un título. Algunos sostienen que existen dificultades para acceder a la educación, relacionadas con la forma de traer documentos de Colombia y validarlos en Costa Rica. No obstante, el factor que más limita este acceso es la situación económica. ${ }^{33}$

Los refugiados encuestados dicen que se sienten muy bien en Costa Rica (70 \%), pero también hay quienes no cuentan con una experiencia tan buena en el país

\footnotetext{
Chaves, "Refugiados colombianos en Costa Rica", 131.

Chaves, "Refugiados colombianos en Costa Rica", 57.

Chaves, "Refugiados colombianos en Costa Rica", 185

Chaves, "Refugiados colombianos en Costa Rica", 139

Chaves, "Refugiados colombianos en Costa Rica", 144.
} 
(23 \%). Un $62 \%$ planea permanecer en ese Estado, mientras un $36 \%$ no tiene interés en ello. ${ }^{34}$

La percepción de los costarricenses frente a los refugiados estuvo ligada al imaginario de una relación directa entre el colombiano y el narcotráfico, el lavado de dinero y la violencia. ${ }^{35}$ De esta manera, la población migrante tuvo que luchar contra el estigma social de un problema que no los representa a ellos como personas ni como sociedad colombiana. Además de lo anterior, el colombiano busca superar su relación con una condición de refugio que supone una situación de victimización por el conflicto armado y busca seguridad en Costa Rica como salida frente a lo que vive en Colombia.

Lo mencionado es una clara muestra de que estos colombianos refugiados tuvieron algunas dificultades para adentrarse en la sociedad costarricense, en especial por su condición de refugiados y colombianos, lo cual acrecentaba el prejuicio sobre ellos. Entonces, la integración social no fue general; como lo evidencia el estudio, algunos esperaban encontrar refugio en otro país o volver a Colombia, en caso de seguir en dicha situación (Tabla 4).

Costa Rica resultó una buena opción para los colombianos que buscaban una condición económica estable y un país pacífico donde establecerse. Como se dijo, los inmigrantes han llegado a este país por razones más allá de la guerra y esto lo demuestran las condiciones de vida de esta población: como primer factor, sus ocupaciones han girado en torno a rubros como el comercio, la prestación de servicios y la industria manufacturera (Tabla 5), que muestra una posible migración económica y empresarial de comerciantes que observan el territorio costarricense como buena opción para sus negocios y ambiciones profesionales.

Según el tipo de migrante y de sector económico al que se dedica, los colombianos cuentan con mayores oportunidades de empleo que otras poblaciones inmigrantes como los nicaragüenses, lo que se refleja en una menor tasa de desempleo. ${ }^{36}$ Esto se relaciona con la actividad que realiza, que va de la mano con el enfoque de la economía costarricense hacia el área de servicios y comercio; ello, a su vez, está ligado con su tendencia a la concentración de esta población, sobre todo en zonas

Chaves, "Refugiados colombianos en Costa Rica", 179

Chaves, "Refugiados colombianos en Costa Rica", 56.

36 Abelardo Morales, "Inmigración en Costa Rica: características sociales y laborales, integración y políticas públicas", serie Población y desarrollo núm. 85, ed. Cepal (Santiago: Cepal, 2008), 34. 
urbanas. Las provincias donde se han asentado los colombianos son San José (8.611), Heredia (3.081) y Alajuela (1.884) (Mapa 1), que son los lugares en donde han encontrado las mejores oportunidades de trabajo y mayor calidad de vida en cuanto a vivienda y servicios sociales y en donde abundan los negocios de colombianos.

Asimismo, la población colombiana en el mercado laboral costarricense se destaca como patrona o socia activa (26,3\%), trabajadora independiente (25,6 \%) o empleada en empresas privadas $(36,8 \%),{ }^{37}$ lo que le da una mayor independencia económica que a otros inmigrantes y una condición socioeconómica estable.

A los nicaragüenses se los percibe como peligrosos, amenazantes, menos estudiados, pobres e inferiores; ello está motivado por los medios de comunicación que aumentan los prejuicios y la discriminación. Todo esto se ve influenciado por dos factores: en primer lugar, los nicaragüenses cuentan con menor escolaridad y se dedican al sector agropecuario o a la industria manufacturera como mano de obra barata; en segundo lugar, la cantidad masiva de inmigrantes de este país centroamericano y las condiciones económicas precarias en las que llegan a Costa Rica. ${ }^{38}$ Esto provoca una mayor percepción negativa de los nicaragüenses que de los colombianos.

En varias encuestas realizadas en el país se refleja la percepción de los costarricenses sobre los colombianos y dan cuenta de las diferencias ante los nicaragüenses. Para 2006, la percepción positiva de los colombianos era de un 52,4\%, mientras que de los nicaragüenses era de 40,5\%, frente a un 70,1 \% de los nacionales. ${ }^{39}$ Para 2012, la percepción positiva de los colombianos fue de 26,7 \% y la negativa de $46,8 \%$. Para los costarricenses, los colombianos están asociados con el narcotráfico, ${ }^{40}$ en línea con la tendencia de percepción negativa relacionada con el problema de la droga y la violencia en el país que se hacía notable para los refugiados. Los costarricenses suelen ver a los colombianos según el contexto del país: Colombia es una Nación en conflicto, a lo cual los nacionales lo relacionan con una cultura de violencia y miedo y a los colombianos, con una población amenazante y peligrosa. ${ }^{41}$

37 Morales, "Inmigración en Costa Rica", 40.

38 David Delgado, "Modelos de incorporación de inmigrantes: Teorías y perspectivas", Revista de Ciencias Sociales 3-4, núm. 117-118 (2007), 43-55; Delgado, "Percepciones de la inmigración e integración en Costa Rica", 65-91.

39 Delgado, "Percepciones de la inmigración e integración en Costa Rica", 85.

40 Dirección General de Migración y Extranjería de Costa Rica. "Informe nacional: migración e integración en Costa Rica". http://www.migracion.go.cr/institucion/informes/varios/Migracion\%20e\%20Integracion\%20 en\%20Costa\%20Rica\%20Informe\%202012.pdf (acceso octubre 8, 2017), gráfico 3.

41 Delgado, "Modelos de incorporación de inmigrantes: Teorías y perspectivas", 51. 


\section{Testimonios y experiencias de la migración colombiana en Costa Rica}

Para soportar la idea de que Costa Rica es un escenario de contrastes en torno a las migraciones que mantiene un cierto recelo ante la proliferación masiva de estas poblaciones, se hace necesario entrevistar a colombianos que han vivido en Costa Rica para averiguar cómo ha sido su vivencia en el país centroamericano.

Se ha escogido una muestra pequeña, pero importante, de seis migrantes colombianos, para evidenciar la experiencia de estas personas en varios aspectos de su estancia, con énfasis en la integración y la percepción de los colombianos en Costa Rica.

Como lo muestra la Tabla 9, este grupo está compuesto por tres mujeres y tres hombres. La mayoría ha tenido una estancia larga en Costa Rica, con una media de once años de residencia. En la muestra solo hay una mujer por debajo de los 30 años, mientras los demás comprenden edades entre los 36 y los 57 años; no hay una tendencia marcada sobre los motivos de migración en el muestreo (Tabla 9).

A raíz de estas entrevistas, se resaltarán ciertas conclusiones y puntos en común entre las experiencias de los colombianos en Costa Rica que complementarán el análisis hecho a lo largo del texto. En primer lugar, todos los entrevistados resaltaron los beneficios de vivir en ese país: las oportunidades laborales, la calidad de vida, la sostenibilidad económica y la seguridad.

Desde mi punto de vista, sería que se hace por buscar un mejor vivir. Conozco mucho colombiano trabajador que llegó con las manos limpias y aquí encontró lo que ni en cien años hubiera logrado en Colombia; me cuento entre ellos. Y no es que estemos tapados en dinero; es no tener deudas, tener trabajo, poder ir a un lugar de descanso hermoso sin tener que empeñar hasta la plancha. ${ }^{42}$

En segundo lugar, aunque subrayan las ventajas de vivir allí, también destacan algunos detalles desventajosos del país, como el costo de vida demasiado alto. Para algunos resulta exagerado y consideran que no está acorde con la calidad de vida que se recibe. Esta situación ha ido aumentando con el tiempo:

42 Informante 1, Entrevista única, 2017. 
Costa Rica es un país carísimo, pero caro; te digo, es más caro que vivir en Madrid [...]. En Costa Rica es exagerado el costo de vida, el costo del transporte [...] sin tener ninguna razón; es que yo no le encuentro ninguna razón lógica para que aquí, que es el país tropical, no sé, un kilo de tomates, vengo del supermercado cuando me escribiste, el kilo de tomate estaba a 1.700 colones, a 9.000 pesos un kilo de tomate [...]. O sea, ¿y por qué aquí 9.000? Si es sembrado aquí, es cosechado aquí, es un país tropical, tiene todos los climas. Y eso pasa con todo: una Coca-Cola de dos litros vale 11.000 pesos. Entonces uno dice, ¿y por qué?, es Costa Rica, pero es como si uno dijera es que no estoy en Luxemburgo, que hay seguridad; en cambio, aquí también roban, también matan, así que uno diga [...] estoy en una ciudad intermedia. Eso le rompe el bolsillo a quien sea, si bien a mi esposa le duplicaron su salario cuando nos vinimos, pero creo que el negocio no es favorable para nosotros, la ecuación, o sea, nosotros con la mitad de la plata que ganamos hoy en día, por parte de mi esposa, viviríamos mejor en Colombia [...]. ${ }^{43}$

Es un buen país, el problema es que se hizo muy caro, eso tiene que ver con el Gobierno mismo. A ese, entonces, se hizo un país muy corrupto, demasiado corrupto, pero sigue siendo bueno, solamente que es demasiado caro. Hay muchas comparaciones, por ejemplo, ahora que yo vivo aquí en Las Vegas, aquí yo lo que me cuesta una botella de agua allá, yo aquí con lo mismo compro veinte botellas de agua. Y la calidad de vida es muy diferente; es un país muy abusivo [...]. Por ejemplo, con el precio en dólares, es un país que no es dolarizado y tiene su moneda oficial y por Constitución, empezaron a cobrar impuestos en dólares, cuando eso es ilegal, es ilegal porque no está por Constitución, es ilegal, pero para ellos no. Si uno va y lo pelea en un juicio, eso es ilegal. Entonces, es un país abusivo, descarado y sinvergüenza donde lo quieren a uno explotar [...].44

En tercer lugar, ninguno de los entrevistados aseguró sentir discriminación o racismo por parte de los costarricenses.

En cuarto lugar, afirman que los costarricenses son amables en todo sentido con el extranjero, pero al conocerlos más, los entrevistados han caracterizado a los costarricenses como egoístas e hipócritas, en quienes no se puede confiar todo el

Informante 2, Entrevista única, 2017.
Informante 4, Entrevista única, 2017. 
tiempo y se debe ser prevenido, en especial en cuestiones laborales; que por ello, la mayoría no ha entablado amistad con la población local, sino con los extranjeros:

El tico es muy amable con el turista, con el del extranjero turista de cualquier nacionalidad [...]. Cuando esa misma persona de la nacionalidad que sea, dice "oiga, yo me quiero quedar aquí en Costa Rica", todo cambia, porque ya el tico no es amable, no es pura vida, no es sociable, no te ayuda en lo más mínimo. Cuando es de turismo, corren, porque todo tiene una propina, todo tiene un coste: "mire, yo le consigo un tour, yo lo llevo, yo lo traigo" y te cobra por todo. Pero cuando usted le dice: "Venga, ¿habrá una posibilidad de quedarme aquí, de ayudar de trabajar o algo así?", son los más "mierdas" del mundo, los más cerrados, los más egoístas, los más tramposos, los más fariseos, los más... o sea, es una personalidad horrible. El tico es una persona bien difícil; es chismoso, el tico. Nunca te va a decir la verdad en la cara, o sea, puntualmente $[\ldots]^{45}$

Son egoístas, son gente muy egoísta y muy hipócrita. Uno tiene la percepción de decir las cosas en la cara, sin desdén. Y pues uno siempre es uno, aquí o allá, siempre es uno. En cambio, el tico se acopla con la persona con la que esté; digamos, aquí uno no le tiene confianza a los ticos, con los colombianos es con algunos, pero toca tener cuidado con los ticos, porque son muy hipócritas y a ellos no les importa hacerte el mal si ellos quedan bien [... . . ${ }^{46}$

Ellos son muy sociables, pero son muy falsos. No son amigos de nadie. A usted le ofrecen una amistad de frente, pero si usted les da la espalda, de ellos no se pueden confiar [...] ellos son amigables con cualquier tipo de extranjero que llegue. Es un país maravilloso, es solo que no son amigos de nadie, ellos son amigos de frente y prometen y juran, pero cuando usted les da la espalda, le meten el puñal. ${ }^{47}$

También sostienen que el "tico" es una persona que le gusta vivir bien, pero sin trabajar mucho y, por ello, en este país los extranjeros se encuentran en los sectores económicos bajos — los nicaragüenses o demás centroamericanos- $u$ ocupando puestos directivos y de un sector productivo alto —colombianos o

\footnotetext{
Informante 2, Entrevista única, 2017.

Informante 5, Entrevista única, 2017.

Informante 4, Entrevista única, 2017.
} 
demás extranjeros- La mano de obra tica se encuentra en el rango medio y se conforma con ello:

Otra cosa: no son los más trabajadores del mundo. Es muy común que un tico aquí te rechace un ascenso en tu empresa. Mi esposa decía: "Pero mira, íbamos a ascender a Fulano, pero dijo que no, que no quería que lo ascendieran", que el ascenso implica un mayor salario, pero más responsabilidad y te dicen: "No, mire, muchas gracias. Yo no quiero esa responsabilidad; déjeme aquî". Que para uno, yo no sé, para mí es casi inconcebible, porque si tu jefe te ve que tienes el potencial o la capacidad para desarrollar x cargo o x responsabilidad [...] pero es muy normal que eso pase. El tico, entre menos trabaje y menos se joda, más feliz es y aquí el lema es "pura vida para todos". Así se saludan y se despiden entre ellos. ${ }^{48}$

Los entrevistados también mencionaron que cuando el colombiano encuentra oportunidades en este país, evoluciona y mejora su vida de manera considerable, porque por la caracterización del colombiano - trabajador y que busca salidas constantemente- llama mucho la atención del tico y eso le ha abierto puertas. Por ello, es muy común encontrar en algunos lugares de Costa Rica varios restaurantes, cafeterías, tiendas y locales colombianos; lo que produce el colombiano le gusta mucho al tico, por lo que ha proliferado este tipo de establecimientos, en especial en San José:

Pero también el colombiano aquí tiene fama de trabajador, de emprendedor. Hay muchísimas franquicias colombianas como también pequeños negocios; no sé, la ferretería, la carpintería colombiana, el montallantas que, mal que bien, a la final terminan empleando mano de obra costarricense. Al colombiano por lo general le va bien cuando ya se logra enganchar [...]. Acá se trae mucho producto colombiano, que los colombianos traen para vender $[\ldots]{ }^{49}$

Aquí, si yo voy al centro de San José, se ven bastantes panaderías colombianas [...] veo en la calle gente con su gorra colombiana o su camisa vendiendo. Entonces, la visión que tiene el costarricense de nosotros es que venimos a trabajar y a negociar, que no nos quedamos atrás, que siempre buscamos la manera [...]. Ahorita que yo perdí mi trabajo, que di con un grupo de apoyo,

\footnotetext{
Informante 2, Entrevista única, 2017.

49 Informante 2, Entrevista única, 2017.
} 
un grupo de hombres, de una vez me dijeron: "¿Qué sabes hacer? ¿Empanadas, arepas?". Yo les dije que sí [...], entonces me dijeron "tráigalas, que aquí se las compramos"; entonces, todo lo que yo hago me lo compran. Entonces, sí están dados ellos a ayudarnos, a apoyarnos y saben que nosotros lo vamos a hacer sin temores, sin vergüenzas. ${ }^{50}$

En quinto lugar, para algunos entrevistados, el hecho de ser colombianos ha sido una ventaja en este país, debido a que han sido bien recibidos y consideran que el colombiano es popular en esta sociedad y logra expresarse y comunicarse muy bien para destacar entre los demás:

Sí, pues digamos, a los colombianos nos quieren demasiado, como haga de cuenta: somos como la gente popular, somos gente luchadora, les encanta como hablamos, como bailamos, lo que comemos. Cuando decimos que somos colombianos nos dicen como "ay que chévere, son colombianos, cómo hablas". ${ }^{51}$

Bueno, en general, la gente es muy amable. Al ser colombiano, atraes; es como un imán. Si por algún lugar yo llego y hay una reunión que están callados, yo puedo decir: "Oigan, miren, yo soy colombiano". Ya con eso sé que voy a llamar la atención, voy a tener buena acogida, voy a tener buenas conversaciones. Eso es muy bonito; ser colombiano es muy bonito. Me he sentido muy halagado, tanto con la comida, nuestra cultura, por las novelas, todo; conocen demasiado por las novelas, entonces he recibido una muy buena acogida por parte de ellos. ${ }^{52}$

En sexto lugar, los entrevistados resaltan que, si bien el trato y recibimiento ha sido bueno, con el paso del tiempo sí ha habido un cambio en la percepción del costarricense sobre todo del colombiano que lleva más de siete años viviendo en el país centroamericano frente a aquellos que llegaron hace poco. Antes, la amabilidad y el recibimiento fueron más notables. Algunos colombianos justifican este cambio, debido a que aunque son pocos, unos han ido allá en busca de oportunidades delictivas o ilegales, pues en varios hechos de ese tipo se encuentra un colombiano involucrado; también sostienen que, en ocasiones, la forma de ser del colombiano ha chocado con la personalidad del costarricense, por lo que los colombianos se han vuelto un poco más pasivos y respetuosos de la cultura del país que los acoge:

Informante 6, Entrevista única, 2017.

Informante 5, Entrevista única, 2017.

Informante 6, Entrevista única, 2017. 
La adaptación dura unos años, pero es más por las costumbres que se traen, que no son muy buenas, como por ejemplo, llegar a seguir haciendo fiestas bulliciosas, más los que llegamos de climas caliente, porque creo que somos los más alborotados y creemos que podemos seguir haciendo lo mismo. Ese fue el primer conflicto y en reuniones con compatriotas escuché lo mismo [...]. La mayoría llegan muy agresivos, se traen los afanes en carretera y en comercio. Aquí se respeta los trancones; nadie pita como allá. Por eso nos cuesta al principio las reglas de aquí [...]. Pero cuando se aprende a respetar, mejora mucho. Ellos son un poco apáticos, pero pienso que algo de razón tienen: sienten invadido su espacio. Pero este país ha mejorado mucho por los extranjeros, porque la mano de obra de aquí es muy mala. Aparte, son pura vida, muy tranquilos y la combinación del acelere del colombiano los ha despertado algo. ${ }^{53}$

Pues los costarricenses, la mayoría de los costarricenses son amables. En el principio, cuando yo llegué, al inicio de la década de los 2000 [...] cuando llegué la gente era muy amable, muy querida. Yo podía preguntarle en la oficina a alguien y me quedaba sorprendida por cómo esa persona podía querer acompañarte y ubicarte muy bien, la amabilidad de la gente [...]. Los costarricenses se caracterizan por ser muy amables y también muy pasivos frente a los colombianos, que somos como muy impulsivos frente a hacer cosas, de querer salir adelante o tenemos mucha malicia indígena, como dice el dicho, mientras que los costarricenses son como más pasivos, como más tranquilos. No están acostumbrados a ver tanta cosa mala, entonces, cualquier cosa los sorprende. Poco a poco eso ha ido cambiando, porque pues la situación en Costa Rica poco a poco se ha puesto un poco más tenue, como que ocurren más cosas horribles, entonces, poco a poco hasta la cultura ha ido cambiando. ${ }^{54}$

En séptimo lugar, los colombianos entrevistados destacaron que sí existe un cambio notable entre la percepción del tico sobre el colombiano y el nicaragüense. Ellos consideran que sí existe rechazo a los nicaragüenses. Se les llama "nica" de forma despectiva, como si fuera un insulto. Esto se relaciona con el tipo de labores de los nicaragüenses, que son del sector primario (campo) o tareas no profesionales, como servicio doméstico, vigilancia, etc. Son trabajos que el costarricense ya no desea desempeñar y, por eso, llega el migrante nicaragüense a suplir estas necesidades.

53 Informante 1, Entrevista única, 2017.

54 Informante 3, Entrevista única, 2017. 
El costarricense sí tiene un trato distinto hacia los nacionales del país fronterizo, que es discriminatorio y de rechazo:

Sí, claro: aquí al nicaragüense no le dicen nicaragüense, sino que le dicen nica y el nica... [...]. El nicaragüense es el que hace el trabajo sucio, por decirlo así, o sea, es la empleada del servicio, es el jardinero, es el vigilante, es el agricultor, es el que cosecha el café. Porque el tico tiene un ego muy grande en todos los estratos sociales, o sea, esos trabajos son mal vistos para que los haga un costarricense. Entonces, si sacan a todos los nicaragüenses de Costa Rica, este país se jode, porque no hay quien haga las labores básicas. Pero claro que lo discrimina el tico, claro que lo mira de hombro para abajo; claro que se siente superior al nicaragüense. ${ }^{55}$

Bueno, ahí si es diferente que con los colombianos. Ahí sí hay una especie de rechazo. Les dicen nicas y decirles nicas es como decirles algo despectivo. A veces, a algunos se les señala que son ladrones, o que vienen a tener trabajos peores y eso porque el costarricense ya no quiere trabajar en el campo, entonces, contrata a los nicaragüenses; entonces, los peores trabajos son para los nicaragüenses. Muchas empleadas de servicio son nicaragüenses. Pero también, algunos vienen aquí a colocar sus negocios, sodas — que son como cafeterías-, preparan sus empanadas, sus buñuelos de allá. Pero sí hay una especie de rechazo. ${ }^{56}$

\section{Conclusiones}

Costa Rica es un país de migrantes que, desde el inicio de su historia, se ha nutrido por la población de otras nacionalidades. No siempre esta migración ha sido plenamente aceptada y recibida, si bien el costarricense es amable y amigable con todo extranjero. En las últimas décadas, la migración ha aumentado considerablemente en este país y, con el paso del tiempo, se han evidenciado cambios en las percepciones al respecto. El colombiano no ha sido rechazado o discriminado, pero esto ha comenzado a cambiar, porque se ha adoptado paulatinamente una visión negativa de él, debido a su migración masiva y a las situaciones perjudiciales que se han presentado en la Nación en las que colombianos se han visto involucrados.

55 Informante 2, Entrevista única, 2017.

56 Informante 6, Entrevista única, 2017. 
Por otra parte, existe una nacionalidad que sí ha sido discriminada en Costa Rica: la nicaragüense, que convive con el estigma despectivo sobre ella y las labores que realiza. Así, es posible observar que aún existe segregación en Costa Rica frente al nicaragüense y, en cierta medida, el colombiano.

Los colombianos han logrado mejorar sus condiciones de vida en Costa Rica y se les han reconocido más derechos y generado mejores oportunidades.

En su mayoría, son empresarios y profesionales que buscan impulsar sus negocios o habilidades comerciales y de servicios en el país. Sin embargo, el sentido de pertenencia por el sitio donde viven y la conexión y convivencia del lugar donde habitan han sido temas difíciles de tratar y no han llegado a tener mayor relevancia en la vida de estos inmigrantes. Son estos aspectos los que propician la integración real de los extranjeros en un Estado y, como se ha evidenciado, en Costa Rica esto no se ha desarrollado por completo.

Si bien los colombianos seguirán migrando a Costa Rica, porque la perciben como una Nación pacífica y económicamente estable, mientras no haya cambios y concienciación dentro de la población costarricense (no solo frente a los colombianos, sino también a los nicaragüenses y demás), estos extranjeros seguirán sintiéndose estigmatizados y diferenciados. Más allá de las medidas estatales para integrarlos, el verdadero reto radica en cambiar el pensamiento de los nacionales frente a estas personas.

Aunque se les reconozca nacionalidad costarricense y se les otorguen los mismos derechos que los nativos, tanto los inmigrantes como sus hijos nacidos en Costa Rica continuarán con la etiqueta de extranjeros ante la sociedad costarricense.

\section{Referencias}

Acuña González, Guillermo y Edith Olivares Ferreto. La población migrante nicaragüense en Costa Rica: realidades y respuestas. San José: Fundación Arias para la Paz y el Progreso Humano, 2000.

Aguilar, Luis Ernesto. "Percepciones y actitudes de la población costarricense hacia la inmigración nicaragüense y la emigración de costarricenses al exterior". Pulso nacional, núm. 57 (2008, octubre): 1-26.

Alto Comisionado de las Naciones Unidas para los Refugiados. "Population Statistics". http://popstats.unhcr.org/en/persons_of_concern (acceso octubre 8, 2017). 
Bermúdez, Quendy. "Las leyes anti-inmigratorias y la inmigración china a Costa Rica". Acta Académica, núm. 50 (2012, mayo): 69-92.

Chaves, Marjorie. "Refugiados colombianos en Costa Rica atendidos por la Asociación de consultores y asesores internacionales (ACAI)". Tesis de pregrado para optar por el título de licenciado en trabajo social, Cuidad Universitaria Rodrigo Facio, 2006.

Comisión Económica para América Latina [Cepal]. "Investigación de la migración internacional en América Latina —Imila". http://goo.gl/RkVkLf (acceso noviembre 21, 2016).

Comisión Económica para América Latina. [Cepal]. "Red de datos para áreas pequeñas por microcomputador Redatam". https://goo.gl/fGIU58 (acceso noviembre 21, 2016).

Comisión Interamericana de Derechos Humanos. "Informe n 11/07 Caso interestatal 01/06 Nicaragua c. Costa rica 8 de marzo de 2007”. http://www.cidh.org/annualrep/2007sp/ casointerestatalsp.html (acceso octubre 8, 2017).

Delgado, David. "Modelos de incorporación de inmigrantes: Teorías y perspectivas". Revista de Ciencias Sociales 3- 4, núm. 117-118 (2007): 43-55.

Delgado, David. "Percepciones de la inmigración e integración en Costa Rica". Papeles de población 14, núm. 57 (2008, julio-septiembre): 65-91.

Dirección General de Migración y Extranjería de Costa Rica. "Informe nacional: migración e integración en Costa Rica”. http://www.migracion.go.cr/institucion/informes/varios/ Migracion\%20e\%20Integracion\%20en\%20Costa\%20Rica\%20Informe\%202012.pdf (acceso octubre 8, 2017).

Fonseca, Zaida. "Las migraciones chinas a Costa Rica en el siglo XIX" en Historia comparada de las migraciones en América Latina, coordinado por Patricia Galeana, 161-182. Ciudad de México: Universidad Nacional Autónoma de México, Instituto de Investigaciones Jurídicas, 2016.

Instituto Nacional de Estadística y Censos de Costa Rica. VI censo nacional de población. San José: Dirección General de Estadística y Censos, 1963.

Loría, Marlene y Alonso Rodríguez. "La inmigración china a Costa Rica. Entre la exportación y la exclusión 1870-1910". Revista de historia 2, núm. 44 (2001): 159-192.

Marín, Guiselle. "Españoles en la ciudad de San José a finales del siglo XIX y principios XX". Anuario de Estudios Centroamericanos 2, núm. 25 (1999): 7-31.

Molina, Iván. "Los pequeños y medianos caficultores, la historia y la Nación. Costa Rica (1890-1950)". Caravelle 61, núm. 1 (1993): 61-73.

Morales, Abelardo. "Inmigración en Costa Rica: características sociales y laborales, integración y políticas públicas”, serie Población y desarrollo núm. 85, editado por Cepal. Santiago: Cepal, 2008.

Palma, Mauricio. “¿País de emigración, inmigración, tránsito y retorno? La formación de un sistema de migración colombiano”. Oasis, núm. 21 (2015): 7-28. 
Segura, Gabriela. "Acceso a la regularización migratoria e integración social de las personas migrantes en Costa Rica”. https://estadonacion.or.cr/files/biblioteca_virtual/022/ Equidad/Segura_2016.pdf (acceso octubre 8, 2017).

Woodward, Raymond L. "Las repúblicas centroamericanas" en Historia de América Latina: América Latina Independiente, 1820-1870, editado por Leslie Bethell, 144-174. Barcelona: Crítica, 1991.

\section{Anexos y tablas}

Tabla 1. Población extranjera en Costa Rica por nacionalidad, 2000-2011

\begin{tabular}{|l|l|l|l|}
\hline \multicolumn{1}{|c|}{ Censo 2000 } & \multicolumn{1}{c|}{ Censo 2011 } & \multicolumn{1}{c|}{385.899} \\
\hline Nicaragua & 226.374 & Nicaragua & 287.766 \\
\hline Panamá & 10.270 & Colombia & 16.514 \\
\hline Estados Unidos & 9.511 & Estados Unidos & 15.898 \\
\hline El Salvador & 8.714 & Panamá & 11.250 \\
\hline Colombia & 5.898 & El Salvador & 9.424 \\
\hline Cuba & 4.320 & Venezuela & 3.886 \\
\hline Perú & 2.840 & Cuba & 3.860 \\
\hline Hong-Kong (China) & 2.466 & Honduras & 3.778 \\
\hline México & 2.327 & Perú & 3.404 \\
\hline Guatemala & 1.996 & China & 3.281 \\
\hline
\end{tabular}

Fuente: elaboración propia con base en Comisión Económica para América Latina [Cepal], "Investigación de la migración internacional en América Latina —Imila”, http://goo.gl/RkVkLf (acceso noviembre 21, 2016).

Tabla 2. Población colombiana en Costa Rica según censos 1950-2011

\begin{tabular}{|c|c|c|c|c|c|c|}
\hline Censo & 1950 & 1963 & 1973 & 1984 & 2000 & 2011 \\
\hline Colombia & 312 & 676 & 797 & 1.090 & 5.898 & 16.514 \\
\hline
\end{tabular}

Fuente: elaboración propia con base en Instituto Nacional de Estadística y Censos de Costa Rica, VI censo nacional de población (San José: Dirección General de Estadística y Censos, 1963); Comisión Económica para América Latina [Cepal], "Investigación de la migración internacional en América Latina —Imila", http://goo.gl/RkVkLf (acceso noviembre 21, 2016). 
Tabla 3. Disfrute de garantías sociales de los refugiados atendidos por ACAI (Acnur) en Costa Rica, 2006

\begin{tabular}{|l|c|c|c|c|}
\hline \multicolumn{1}{|c|}{ Garantía social } & Sí (\%) & No (\%) & NS (\%) & NA (\%) \\
\hline Vacaciones anuales & 30,6 & 46,8 & 11,3 & 11,3 \\
\hline Día de descanso semanal & 59,7 & 22,6 & 9,7 & 8,1 \\
\hline Seguro social & 37,1 & 46,8 & 8,1 & 8,1 \\
\hline Póliza de seguro de riesgos de trabajo & 11,3 & 71 & 9,7 & 8,1 \\
\hline Pago de aguinaldo & 22,6 & 51,6 & 14,5 & 11,3 \\
\hline Salario de acuerdo con sus funciones & 29 & 50 & 9,7 & 11,3 \\
\hline Pago de cesantía & 14,5 & 54,8 & 14,5 & 16,1 \\
\hline Preaviso & 16,1 & 50 & 16,1 & 17,7 \\
\hline Condiciones de seguridad en el trabajo & 38,7 & 40,3 & 11,3 & 9,7 \\
\hline
\end{tabular}

Fuente: elaboración propia con base en Marjorie Chaves, "Refugiados colombianos en Costa Rica atendidos por la Asociación de consultores y asesores internacionales (ACAI)", tesis de pregrado para optar por el título de licenciado en trabajo social, Ciudad Universitaria Rodrigo Facio, 2006, 139.

Tabla 4. Comparación entre la situación laboral actual y la condición laboral en Colombia, 2004

\begin{tabular}{|l|c|c|c|}
\hline Condición laboral actual & Masculino (\%) & Femenino (\%) & Total (\%) \\
\hline Igual & 20,3 & 22,4 & 21,3 \\
\hline Peor & 45,9 & 39,5 & 42,7 \\
\hline Mejor & 28,4 & 21,1 & 24,7 \\
\hline NS/NR & 5,4 & 17,1 & 11,3 \\
\hline Total & 100,0 & 100,0 & 100,0 \\
\hline
\end{tabular}

Fuente: elaboración propia con base en Chaves, "Refugiados colombianos en Costa Rica atendidos por la Asociación de consultores y asesores internacionales (ACAI)", 140 . 
Tabla 5. Población colombiana en Costa Rica económicamente activa, mayor de 15 años por actividad laboral

\begin{tabular}{|l|c|c|c|c|c|c|c|}
\hline \multicolumn{1}{|c|}{ Colombia } & \multicolumn{3}{c|}{2000} & \multicolumn{3}{c|}{2011} \\
\hline Actividad laboral (+15) & Total & Hombres & Mujeres & Total & Hombres & Mujeres \\
\hline Agricultura, caza y pesca & 93 & 77 & 16 & 171 & 134 & 37 \\
\hline Minas y canteras & 0 & 0 & 0 & 8 & 5 & 3 \\
\hline Industrias manufactureras & 489 & 340 & 149 & 1.386 & 873 & 513 \\
\hline Electricidad, gas y agua & 11 & 6 & 5 & 59 & 43 & 16 \\
\hline Construcción & 96 & 84 & 12 & 416 & 350 & 66 \\
\hline Comercio, restaurantes y hoteles & 979 & 613 & 366 & 3.916 & 2.135 & 1.781 \\
\hline Transportes y comunicaciones & 131 & 96 & 35 & 772 & 577 & 195 \\
\hline Intermediario financiero/Empresa/Alquiler & 286 & 185 & 101 & 430 & 219 & 211 \\
\hline Servicios comunales, sociales y personales & 764 & 336 & 428 & 2.832 & 1.295 & 1.537 \\
\hline Servicio doméstico & 0 & 0 & 0 & 159 & 8 & 151 \\
\hline
\end{tabular}

Fuente: elaboración propia con base en Comisión Económica para América Latina [Cepal], "Investigación de la migración internacional en América Latina —Imila", http://goo.gl/RkVkLf (acceso noviembre 21, 2016).

Tabla 6. Indicadores de fuerza de trabajo de la población inmigrante por país de origen, 2007

\begin{tabular}{|l|c|c|c|c|}
\hline Nacionalidad & Tasa bruta & Tasa neta & Tasa de ocupación & Tasa de desempleo abierto \\
\hline Colombianos & 62,3 & 71,2 & 69,8 & 2,0 \\
\hline Nicaragüenses & 58,3 & 62,3 & 59,8 & 4,0 \\
\hline Panameños & 51,8 & 58,2 & 58,2 & 0,0 \\
\hline Otros & 53,6 & 58,5 & 57,6 & 1,6 \\
\hline Total & 57,4 & 61,9 & 59,8 & 3,4 \\
\hline
\end{tabular}

Fuente: elaboración propia con base en Abelardo Morales, "Inmigración en Costa Rica: características sociales y laborales, integración y políticas públicas", serie Población y desarrollo núm. 85, editado por Cepal (Santiago: Cepal, 2008$), 34$.

Tabla 7. Distribución porcentual de la población migrante por país de origen y categoría ocupacional, 2007

\begin{tabular}{|l|c|c|c|c|c|}
\hline \multicolumn{1}{|c|}{ Categoría ocupacional } & Colombianos & Nicaragüenses & Panameños & Otros & Total \\
\hline Patrono o socio activo & 26,3 & 3,1 & 8,2 & 16,7 & 6,4 \\
\hline Trabajador por cuenta propia & 25,6 & 15,3 & 10,5 & 19,5 & 16,3 \\
\hline Empleado u obrero del Estado & 0,0 & 1,2 & 12,9 & 9,1 & 2,8 \\
\hline Empleado u obrero de la empresa privada & 36,8 & 64,2 & 60,4 & 47,6 & 60,2 \\
\hline Servidor doméstico (asalariado) & 5,7 & 15,5 & 8,1 & 2,9 & 12,8 \\
\hline Trabajador no remunerado & 5,6 & 0,8 & 0,0 & 4,3 & 1,5 \\
\hline Total & 100,0 & 100,0 & 100,0 & 100,0 & 100,0 \\
\hline
\end{tabular}

Fuente: elaboración propia con base en Morales, "Inmigración en Costa Rica", 40. 
Tabla 8. Distribución porcentual de la población migrante según país de origen, sexo, grado educativo del jefe de hogar y quintiles de ingreso per cápita, 2007

\begin{tabular}{|l|c|c|c|c|c|c|c|c|c|}
\hline \multirow{2}{*}{ Categoría ocupacional } & \multicolumn{7}{|c|}{ País de origen } \\
\cline { 2 - 11 } & Total & NIC & COL & PAN & EE.UU & SLV & PER & MEX & Otros \\
\hline Sexo del jefe de hogar & 100,0 & 100,0 & 100,0 & 100,0 & 100,0 & 100,0 & 100,0 & 100,0 & 100,0 \\
\hline Hombre & 73,5 & 73,3 & 79,3 & 73,1 & 68,9 & 70,4 & 76,3 & 81,6 & 73,6 \\
\hline Mujer & 26,5 & 26,7 & 20,7 & 26,9 & 31,1 & 29,6 & 23,7 & 18,4 & 26,4 \\
\hline $\begin{array}{l}\text { Nivel educativo del jefe } \\
\text { del hogar }\end{array}$ & 100,0 & 100,0 & 100,0 & $100,03,2$ & 100,0 & 100,0 & 100,0 & 100,0 & 100,0 \\
\hline Ninguno & 10,8 & 14,0 & 0,0 & 3,2 & 0,7 & 0,0 & 0,0 & 0,0 & 0,5 \\
\hline Algún grado de primaria & 43,6 & 51,5 & 13,4 & 28,2 & 19,6 & 27,0 & 13,3 & 4,5 & 15,4 \\
\hline Algún grado de secundaria & 29,2 & 28,3 & 39,6 & 33,3 & 35,2 & 32,2 & 26,9 & 22,0 & 30,8 \\
\hline Algún grado superior & 16,2 & 6,0 & 47,0 & 35,3 & 44,6 & 44,6 & 59,7 & 73,5 & 53,3 \\
\hline Ignorado & 0,3 & 0,3 & 0,0 & 0,0 & 0,0 & 0,0 & 0,0 & 0,0 & 0,0 \\
\hline $\begin{array}{l}\text { Quintiles por ingreso per } \\
\text { cápita }\end{array}$ & 100,0 & 100,0 & 100,0 & 100,0 & 100,0 & 100,0 & 100,0 & 100,0 & 100,0 \\
\hline Quintil I & 24,8 & 29,3 & 13,3 & 21,4 & 1,0 & 12,8 & 16,0 & 4,8 & 5,3 \\
\hline Quintil II & 22,3 & 24,2 & 20,4 & 15,2 & 7,8 & 10,7 & 8,3 & 20,4 & 16,1 \\
\hline Quintil III & 23,2 & 26,6 & 9,2 & 15,8 & 23,8 & 14,6 & 3,8 & 0,0 & 10,2 \\
\hline Quintil IV & 16,8 & 15,2 & 29,3 & 25,5 & 30,5 & 15,1 & 28,5 & 4,7 & 20,4 \\
\hline Quintil V & 13,0 & 4,8 & 27,8 & 22,1 & 37,0 & 46,8 & 43,3 & 70,1 & 48,0 \\
\hline
\end{tabular}

Fuente: elaboración propia con base en Morales, "Inmigración en Costa Rica", 32.

Tabla 9. Caracterización de las personas entrevistadas

\begin{tabular}{|l|l|l|l|l|l|l|l|l|l|}
\hline Género & Ciudad & Edad & $\begin{array}{c}\text { Tiempo de } \\
\text { residencia }\end{array}$ & iTrabaja? & Motivo de \\
migración & $\begin{array}{c}\text { ¿Reside } \\
\text { en } \\
\text { Costa } \\
\text { Rica? }\end{array}$ & $\begin{array}{c}\text { iSe insta- } \\
\text { lará defini- } \\
\text { tivamente? }\end{array}$ & $\begin{array}{c}\text { ¿Retor- } \\
\text { naría a } \\
\text { Colombia? }\end{array}$ \\
\hline 1 & F & San Josée & $\begin{array}{c}57 \\
\text { años }\end{array}$ & 8 años & Sí & $\begin{array}{c}\text { Recomendación } \\
\text { familiar }\end{array}$ & Sí & Sí & Sí \\
\hline 2 & M & San José & $\begin{array}{c}36 \\
\text { años }\end{array}$ & 2 años & No & $\begin{array}{c}\text { Recomendación } \\
\text { familiar }\end{array}$ & Sí & No & Sí \\
\hline 3 & M & San Josée & $\begin{array}{c}46 \\
\text { años }\end{array}$ & 17 años* & - & $\begin{array}{c}\text { Recomendación } \\
\text { familiar }\end{array}$ & No & Sí & No \\
\hline 4 & M & Santana & $\begin{array}{c}50 \\
\text { años }\end{array}$ & 16 años* & - & $\begin{array}{c}\text { Motivación } \\
\text { personal }\end{array}$ & No & No & No \\
\hline F & San José & $\begin{array}{c}23 \\
\text { años }\end{array}$ & 8 años & Sí & $\begin{array}{c}\text { Recomendación } \\
\text { familiar }\end{array}$ & Sí & Sí & No \\
\hline 6 & M & Heredia & $\begin{array}{c}42 \\
\text { años }\end{array}$ & 15 años & Sí & $\begin{array}{c}\text { Recomenda- } \\
\text { ción familiar } \\
\text { y migración } \\
\text { laboral }\end{array}$ & Sí & Sí & - \\
\hline
\end{tabular}

Fuente: elaboración propia con base en información recolectada de entrevistas a los informantes sobre migraciones colombianas en Costa Rica.

*Personas que ya no residen en el país 
Gráfico 1. Personas con quienes se comparte vivienda según parentesco en Costa Rica, 2004

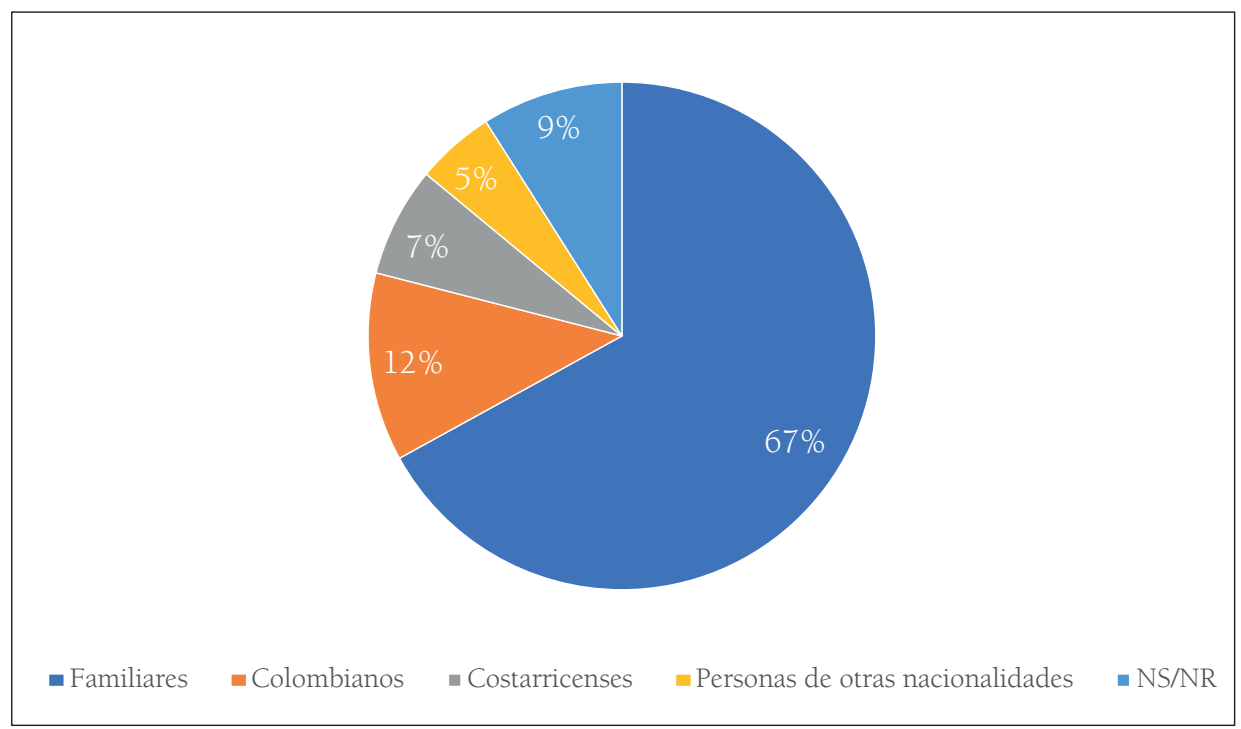

Fuente: elaboración propia con base en Chaves, "Refugiados colombianos en Costa Rica atendidos por la Asociación de consultores y asesores internacionales (ACAI)", 130.

Gráfico 2. Valoración del trato recibido de las personas con quienes comparte labores, 2004

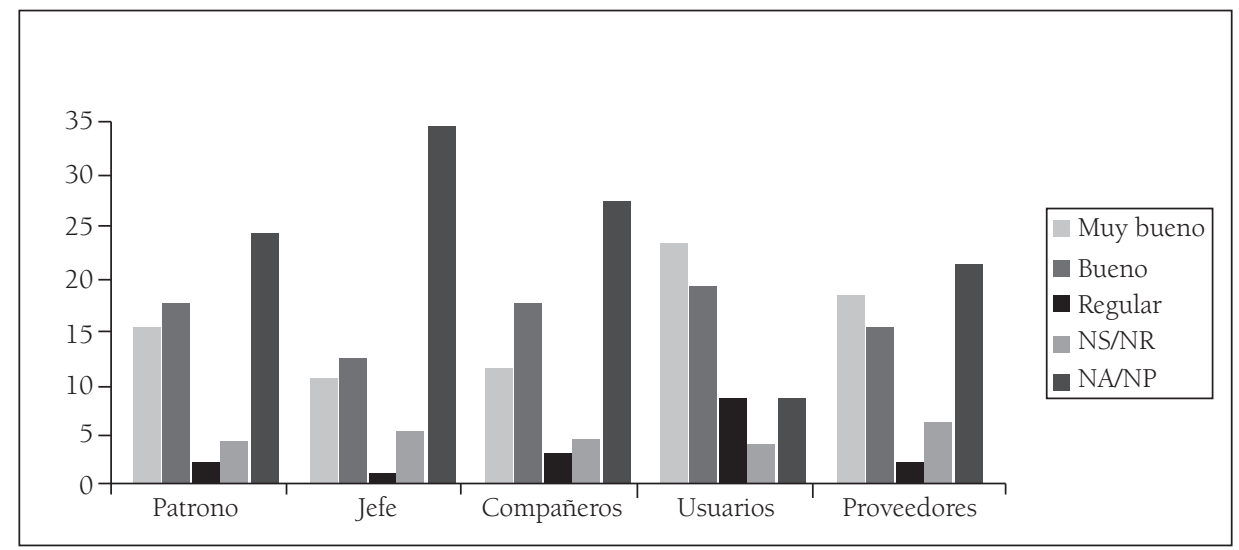

Fuente: Chaves, "Refugiados colombianos en Costa Rica atendidos por la Asociación de consultores y asesores internacionales (ACAI)", 143. 
Gráfico 3. Distribución porcentual de la percepción sobre los colombianos que viven en Costa Rica, 2012

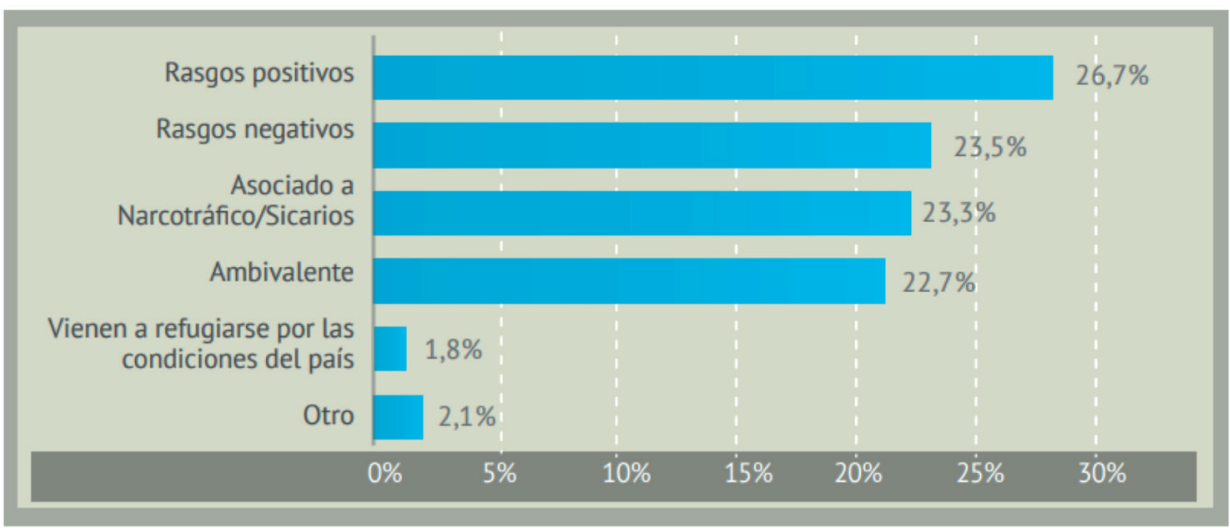

Fuente: Dirección General de Migración y Extranjería de Costa Rica, "Informe nacional: migración e integración en Costa Rica" http://www.migracion.go.cr/institucion/informes/varios/Migracion\%20e\%20Integracion\%20en\%20Costa\%20 Rica\%20Informe\%202012.pdf (acceso octubre 8, 2017), 88.

Mapa 1. Dispersión territorial de los colombianos residentes en Costa Rica, 2010

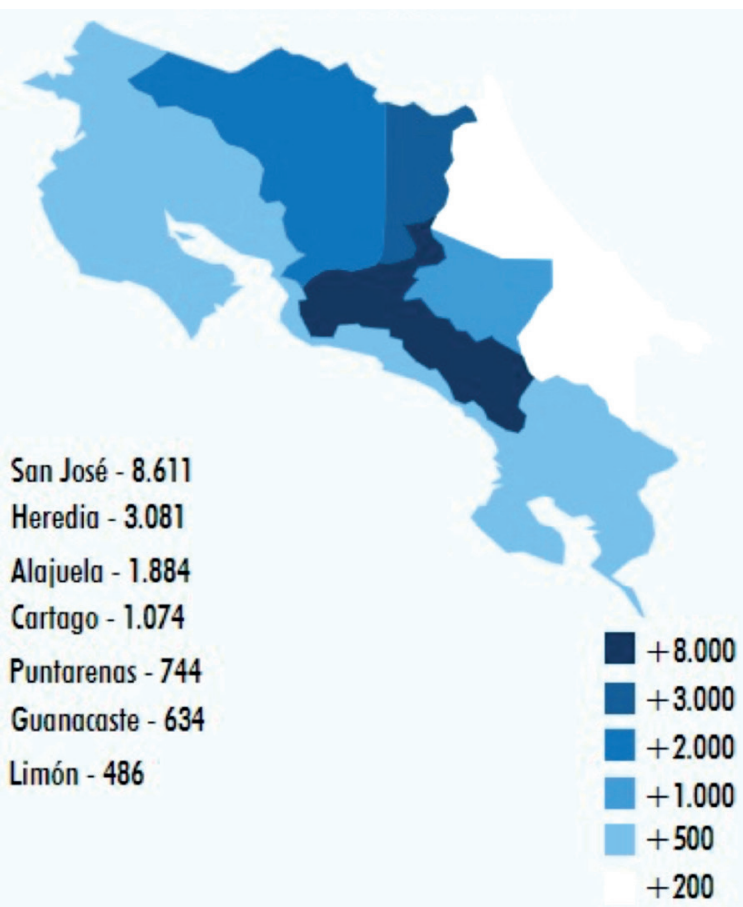

Fuente: elaboración propia con base en Comisión Económica para América Latina [Cepal], "Red de datos para áreas pequeñas por microcomputador Redatam", https://goo.gl/fGIU58 (acceso noviembre 21, 2016). 